\title{
Editorial
}

\section{The New COVID-19 Related Psychological Distress Pandemic}

\author{
Michele Roccella ${ }^{1}\left[\right.$, Gioacchino Lavanco ${ }^{1}$ and Luigi Vetri ${ }^{2, *} \mathbb{C}$ \\ 1 Department of Psychology, Educational Science and Human Movement, University of Palermo, \\ 90128 Palermo, Italy; michele.roccella@unipa.it (M.R.); comunicazioni@gioacchinolavanco.it (G.L.) \\ 2 Oasi Research Institute-IRCCS, Via Conte Ruggero 73, 94018 Troina, Italy \\ * Correspondence: lvetri@oasi.en.it
}

check for

updates

Citation: Roccella, M.; Lavanco, G.; Vetri, L. The New COVID-19 Related Psychological Distress Pandemic. J. Clin. Med. 2022, 11, 237. https:// doi.org/10.3390/jcm11010237

Received: 21 December 2021 Accepted: 28 December 2021 Published: 2 January 2022

Publisher's Note: MDPI stays neutral with regard to jurisdictional claims in published maps and institutional affiliations.

Copyright: (C) 2022 by the authors. Licensee MDPI, Basel, Switzerland. This article is an open access article distributed under the terms and conditions of the Creative Commons Attribution (CC BY) license (https:// creativecommons.org/licenses/by/ $4.0 /)$.
Although a few years have passed since the beginning of the COVID-19 pandemic, a large body of scientific literature is already present on the impact that the worldwide spread of the virus has had on people's quality of life.

The studies conducted on previous decade's epidemics, such as SARS, MERS and the H1N1 flu, as well as the research conducted the day after other types of catastrophes, have shown us the possible psychopathological implications linked to unexpected and massive events, which threaten the health and safety of individuals and undermine the stability of communities.

A total of 50 studies, 48 research articles and 2 reviews, included in the Special Issue "The Impact of the COVID-19 Emergency on the Quality of Life of the General population", fully reflect the complexity and the psychological and health implications caused by the unprecedented health, economic and social emergency provoked by the pandemic spread of the SARS-CoV-2 virus.

The interesting research included in the Special Issue essentially concern three macro-areas.

The first area of interest includes the analysis of the neuropsychological implications determined by the COVID-19 pandemic. These studies already clearly showed that the effects of the rapid spread of an epidemic go well beyond the morbidity and mortality of the infected people, strongly affecting various areas of the entire population's daily life, with inevitable repercussions on mental health [1-5].

The second macro-area analyzed by the studies of this Special Issue concerns the health measures necessary to face the coronavirus emergency, in particular in relation to prevention, treatment, and subsequent follow-up measures. In this phase of coexistence with COVID-19, the territory and its resources represent the crucial place for controlling the epidemic but, at the same time, also the place where new opportunities can be found for prevention and health promotion interventions [6-10].

The third macro-area of interest regarded the effects of the COVID-19 pandemic on the management and evolution of other diseases. Unfortunately, fear is becoming a reality. In an attempt to limit the damage caused by COVID-19, the right to health and care of people with other serious diseases is further jeopardized [11-15].

The outbreak of COVID-19 evidenced the vulnerability of the health system and of the patients with chronic or rare diseases; it also highlighted their needs in terms of access to care, adhesion to a therapy schedule, and home care.

The COVID-19 pandemic represents a catastrophe of global dimensions, the first traumatic event on a global scale in the most recent history of humanity. Although the degree of individual exposure to a traumatic event such as this is extremely variable because of different environmental, personal and professional factors, it can be considered in some ways an "in vivo experiment" in the psychopathology of the masses; heterogeneous for geographical, economic and cultural reasons, the world population is exposed in an extreme and persistent way to the same trauma in a short time.

In summary, the articles in this Special Issue reiterate how the unprecedented health, economic and social emergency that our society is experiencing is causing an increase in 
mental distress in subjects with a pre-existing psychiatric pathology, particularly in health workers, but also in the general population. In particular, the prevalence of symptoms of anxiety, depression, and post-traumatic stress disorder is clearly increasing in the general population, and the scientific community is called to give answers in order to avoid the current viral pandemic turning into a psychological distress pandemic.

Author Contributions: Conceptualization and writing-original draft preparation, G.L., M.R. and L.V.; writing-review and editing, M.R. and L.V. All authors have read and agreed to the published version of the manuscript.

Funding: This research received no external funding.

Conflicts of Interest: The authors declare no conflict of interest.

\section{References}

1. Miceli, S.; Caci, B.; Roccella, M.; Vetri, L.; Quatrosi, G.; Cardaci, M. Do Mental Health and Vitality Mediate the Relationship between Perceived Control over Time and Fear of COVID-19? A Survey in an Italian Sample. J. Clin. Med. 2021, 10, 3516. [CrossRef] [PubMed]

2. Smirni, P.; Lavanco, G.; Smirni, D. Anxiety in Older Adolescents at the Time of COVID-19. J. Clin. Med. 2020, 9, 3064. [CrossRef] [PubMed]

3. Gebska, M.; Kołodziej, Ł.; Dalewski, B.; Pałka, Ł.; Sobolewska, E. The Influence of the COVID-19 Pandemic on the Stress Levels and Occurrence of Stomatoghnatic System Disorders (SSDs) among Physiotherapy Students in Poland. J. Clin. Med. 2021, 10, 3872. [CrossRef] [PubMed]

4. $\quad$ Burke, T.; Berry, A.; Taylor, L.K.; Stafford, O.; Murphy, E.; Shevlin, M.; McHugh, L.; Carr, A. Increased psychological distress during COVID-19 and quarantine in Ireland: A national survey. J. Clin. Med. 2020, 9, 3481. [CrossRef] [PubMed]

5. Flesia, L.; Monaro, M.; Mazza, C.; Fietta, V.; Colicino, E.; Segatto, B.; Roma, P. Predicting perceived stress related to the COVID-19 outbreak through stable psychological traits and machine learning models. J. Clin. Med. 2020, 9, 3350. [CrossRef] [PubMed]

6. Narzisi, A. Phase 2 and later of COVID-19 lockdown: Is it possible to perform remote diagnosis and intervention for autism spectrum disorder? An online-mediated approach. J. Clin. Med. 2020, 9, 1850. [CrossRef] [PubMed]

7. Rogowska, A.M.; Pavlova, I.; Kuśnierz, C.; Ochnik, D.; Bodnar, I.; Petrytsa, P. Does physical activity matter for the mental health of university students during the COVID-19 pandemic? J. Clin. Med. 2020, 9, 3494. [CrossRef] [PubMed]

8. Kludacz-Alessandri, M.; Walczak, R.; Hawrysz, L.; Korneta, P. The Quality of Medical Care in the Conditions of the COVID-19 Pandemic, with Particular Emphasis on the Access to Primary Healthcare and the Effectiveness of Treatment in Poland. J. Clin. Med. 2021, 10, 3502. [CrossRef] [PubMed]

9. Lee, K.-M.; Ko, H.-J.; Lee, G.H.; Kim, A.; Lee, D.-W. A Well-Structured Follow-Up Program is Required after Recovery from Coronavirus Disease 2019 (COVID-19); Release from Quarantine is Not the End of Treatment. J. Clin. Med. 2021, 10, 2329. [CrossRef] [PubMed]

10. Modaberi, S.; Saemi, E.; Federolf, P.A.; van Andel, S. A systematic review on detraining effects after balance and fall prevention interventions. J. Clin. Med. 2021, 10, 4656. [CrossRef] [PubMed]

11. Wańkowicz, P.; Szylińska, A.; Rotter, I. Evaluation of mental health factors among people with systemic lupus erythematosus during the SARS-CoV-2 pandemic. J. Clin. Med. 2020, 9, 2872. [CrossRef] [PubMed]

12. Nieto, R.; Pardo, R.; Sora, B.; Feliu-Soler, A.; Luciano, J.V. Impact of COVID-19 lockdown measures on Spanish people with chronic pain: An online study survey. J. Clin. Med. 2020, 9, 3558. [CrossRef] [PubMed]

13. Pokryszko-Dragan, A.; Chojdak-Łukasiewicz, J.; Gruszka, E.; Pawłowski, M.; Pawłowski, T.; Rudkowska-Mytych, A.; Rymaszewska, J.; Budrewicz, S. Burden of COVID-19 Pandemic Perceived by Polish Patients with Multiple Sclerosis. J. Clin. Med. 2021, 10, 4215. [CrossRef] [PubMed]

14. Filipska, K.; Biercewicz, M.; Wiśniewski, A.; Jabłońska, R.; Królikowska, A.; Główczewska-Siedlecka, E.; Kędziora-Kornatowska, K.; Ślusarz, R. High Rate of Elder Abuse in the Time of COVID-19-A Cross Sectional Study of Geriatric and Neurology Clinic Patients. J. Clin. Med. 2021, 10, 4532. [CrossRef] [PubMed]

15. Maciaszek, J.; Ciulkowicz, M.; Misiak, B.; Szczesniak, D.; Luc, D.; Wieczorek, T.; Fila-Witecka, K.; Gawlowski, P.; Rymaszewska, J. Mental health of medical and non-medical professionals during the peak of the COVID-19 pandemic: A cross-sectional nationwide study. J. Clin. Med. 2020, 9, 2527. [CrossRef] [PubMed] 